\title{
Notch Effect on the Fatigue Behavior of a Hot Dip Galvanized Structural Steel
}

\author{
F. Berto, ${ }^{\mathrm{a}, 1}$ F. Mutignani, ${ }^{\mathrm{a}}$ and M. Tisalvi ${ }^{\mathrm{b}}$ \\ a Department of Management and Engineering, University of Padua, Vicenza, Italy \\ ${ }^{\mathrm{b}}$ Rete Ferroviaria Italiana (RFI), Roma, Italy \\ ${ }^{1}$ berto@gest.unipd.it
}

УДК 539.421

\section{Влияние концентрации напряжений на усталостные характеристики конструкционной стали, гальванизированной методом горячего погружения}

\author{
Ф. Берто ${ }^{\mathrm{a}}$, Ф. Мутиньяни ${ }^{\mathrm{a}}$, М. Тисалви ${ }^{\sigma}$ \\ a Факультет менеджмента и инжиниринга, Падуанский университет, Виченца, Италия \\ ${ }^{\sigma}$ Компания RFI, Рим, Италия
}

Исследовано влияние гальванического покрытия на усталостную прочность конструкиионной стали S355. Несмотря на наличие в литературных источниках экспериментальных данных по гладким образиам из этого материала с покрытием, почти отсутствуют таковые по образиам с кониентраторами напряжений. Выполнен сравнительный анализ образцов $c$ центральным отверстием, подвергнутых гальванизации методом горячего погружения, $u$ исходных образиов той же геометрии. Усталостные испытания проводились при двух постоянных значениях асимметрии циикла нагружения. Получено и проанализировано 60 новых экспериментальных данных.

Ключевые слова: оцинкованная сталь, многоцикловая усталость, влияние концентрации напряжений, коэффициент концентрации напряжений.

Introduction. Hot-dip galvanizing is a surface treatment that aims to protect components from corrosion. Galvanizing is found in almost every major application and industry where steel is used. The utilities, chemical process, construction, automotive, and transportation industries, to name just a few, historically have made extensive use of galvanizing for corrosion control. Hot-dip galvanizing (HDG) has a proven and growing history of success in myriad of applications worldwide.

While the monotonic behavior of steel is not greatly affected by the presence of the zinc layer, except for the yield stress, under cyclic stress the fatigue strength is usually reduced as discussed in [1] dealing with high-strength steels without any stress concentration effect or geometrical discontinuity. In [1], it was found that the fatigue strength is generally correlated to the coating thickness with a reduction of the fatigue life increasing the thickness of the zinc layer. On the other hand, other authors did not support any correlation of loss of the fatigue strength with the coating thickness $[2,3]$. The effect of a galvanizing coating on the fatigue strength of unnotched ferritic steel has been extensively studied in [4] and a tool based on the Kitagawa-Takahashi diagram (see Fig. 1) has been employed for the prediction of the fatigue resistance of hot-dip galvanized steel. Bending fatigue tests were carried out on galvanized proper steels to determine whether the 


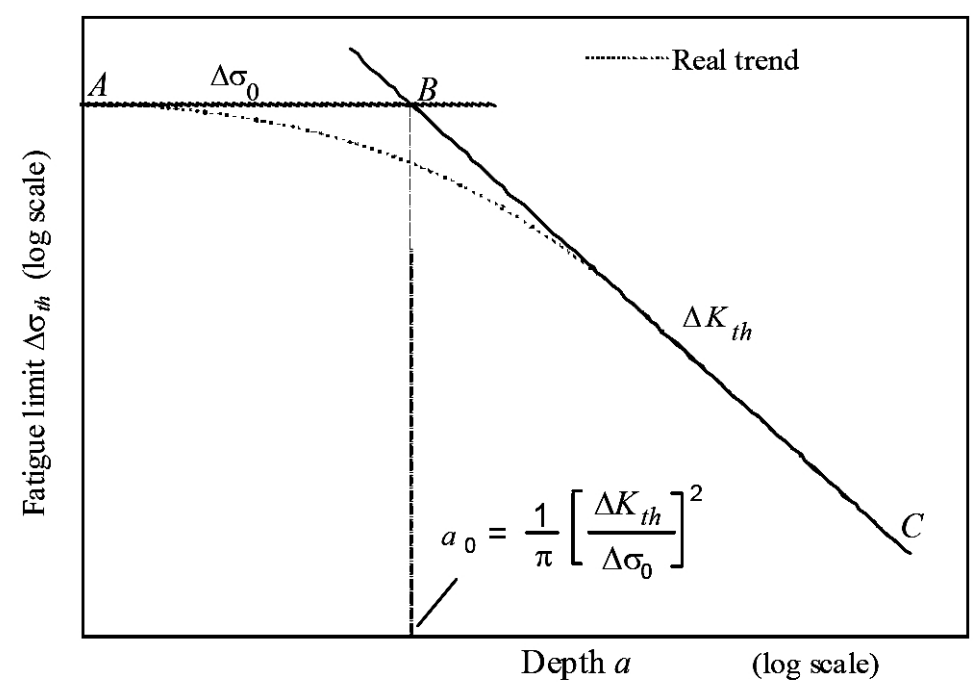

Fig. 1. Fatigue strength according to the Kitagawa-Takahashi diagram.

fatigue resistance of a ferritic steel was affected by the coating. A threshold value in the coating thickness from which the fatigue strength of a ferritic steel can be reduced. It was proved that the fatigue strength behavior of the considered steel is not affected by the zinc layer if the thickness does not exceed $60 \mu \mathrm{m}$. Dealing with galvanized steel wires for bridges construction some interesting and recent studies have been performed in $[5,6]$. A comparison between the fatigue behavior of two hot-dip galvanized steel with similar static load-bearing capability, for automotive applications has been carried out in [7,8]. The fatigue life behavior of galvanized rear axles made of microalloyed steel for automotive application was investigated in [9]. Other important aspects tied to the galvanizing process are well discussed in [10-15]. A wide synthesis and review of applications connected with hot dip galvanized steels can be found in [16].

Although some results on fatigue tests of unnotched specimens are currently available in the literature, there only few ones on notched components. At the best of authors' knowledge, the only complete set of data from notched specimens is due to Huhn and Valtinat [17] who carried out low- and high-cycle fatigue tests of members with holes and bearing-type connections with both punched and drilled holes, but without any preload of the fasteners. The test specimens consisted of S 235 JR G2 (formerly: RSt 37-2) steel and the loading was of simple sinus wave form, while the ratio between the lower and upper tension in the net section was +0.1 . Members with holes and bearing-type connections are compared. The members with a hole were able to withstand a higher stress range $\Delta \sigma$ at the same number of cycles $N$ up to failure than the joints. A comparison between the test specimens with punched holes and those with drilled holes showed the negative influence of punching. The $S-N$ curve for both different structural members with punched holes lied below the corresponding $S-N$ curve for drilled holes. However, a direct comparison between uncoated and hot-dip galvanized notched steel is not available in [17] and it is not possible to understand the fatigue strength reduction due to the galvanizing process. The main aim of the present paper is to partially fill this lack considering uncoated and hot-dip galvanized specimens made of structural steel S355 weakened by a central hole. Four new fatigue sets of data are summarised in the present paper considering two values of the nominal load ratio $R$. The reduction of the fatigue strength due to the presence of the zinc layer is fully investigated. 


\section{Fatigue Tests on Uncoated and Hot-Dip Galvanized Structural Steel S355.}

1.1. Material and Experimental Procedure. Fatigue tests have been carried out on S355 structural steel. It is commonly employed in typical applications such as follows:

(i) structural steel works: bridge components, components for offshore structures;

(ii) power plants;

(iii) mining and earth-moving equipment;

(iv) load-handling equipment;

(v) wind tower components.

The fatigue tests were conducted on a servo-hydraulic MTS 810 test system with a load cell capacity of $250 \mathrm{kN}$. All uniaxial stress-controlled tensile fatigue tests were carried out over a range of cyclic stresses at $10 \mathrm{~Hz}$. Two different load ratios, $R=0$ and $R=-1$ (see Fig. 2), have been considered in the tests both for uncoated and hot-dip galvanized specimens for a total of four new fatigue series.

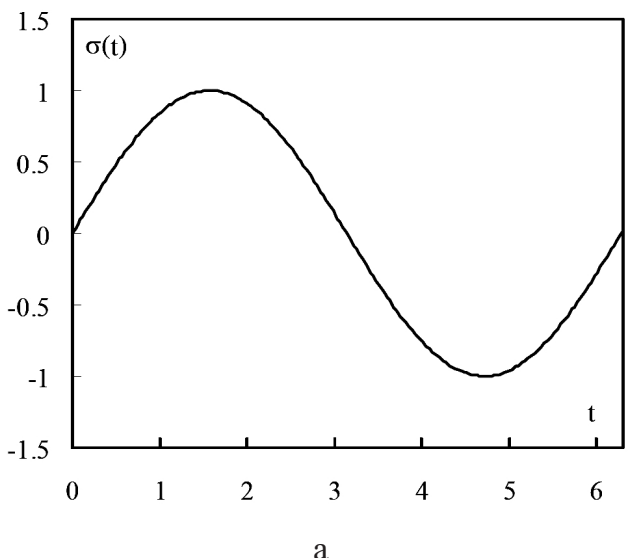

a

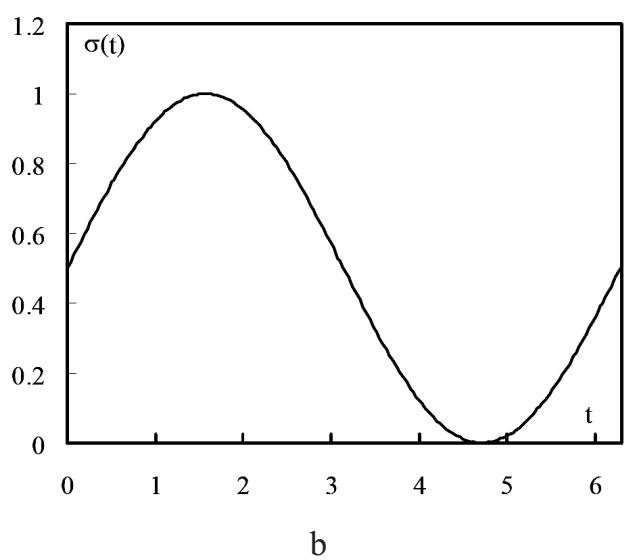

Fig. 2. Wave forms for each loading pattern: (a) loading at $R=-1$; (b) loading at $R=0$.

1.2. Specimen Geometry. A total of four sets of samples have been cut from a sheet: all specimens had rectangular cross section (net area equal to $300 \mathrm{~mm}^{2}$ and gross area equal to $400 \mathrm{~mm}^{2}$ ) and the same geometry and dimensions shown in Fig. 3. The diameter of the hole is equal to $10 \mathrm{~mm}$ resulting in a stress concentration factor $K_{t, \text { net }}$ referred to the net area equal to 2.45 and a $K_{\text {t,gross }}$ equal to 3.27 . The specimen holes were obtained by drilling. Galvanizing of the steel specimens was carried out at about $440^{\circ} \mathrm{C}$ in a zinc bath keeping the specimens inside the bath for four minutes. The specimens were cleaned at room temperature to eliminate the surface scratches due to the process. The coating thickness varied between 90 and $104 \mu \mathrm{m}$ as visible from the broken specimen after the fatigue test shown in Fig. 4.

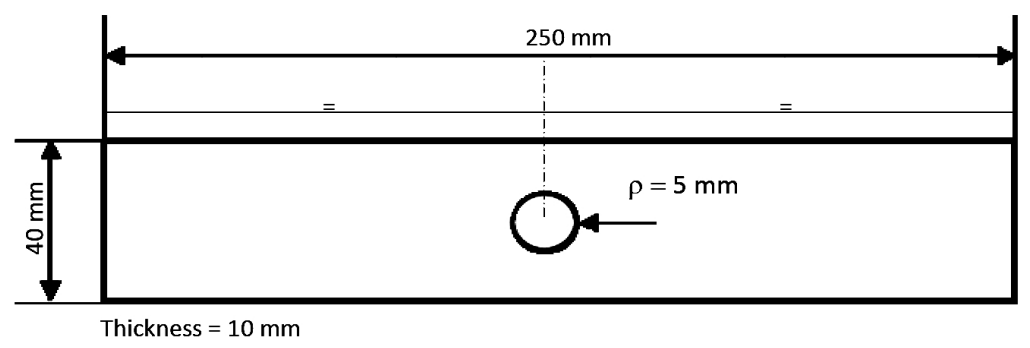

Fig. 3. Specimen geometry. 


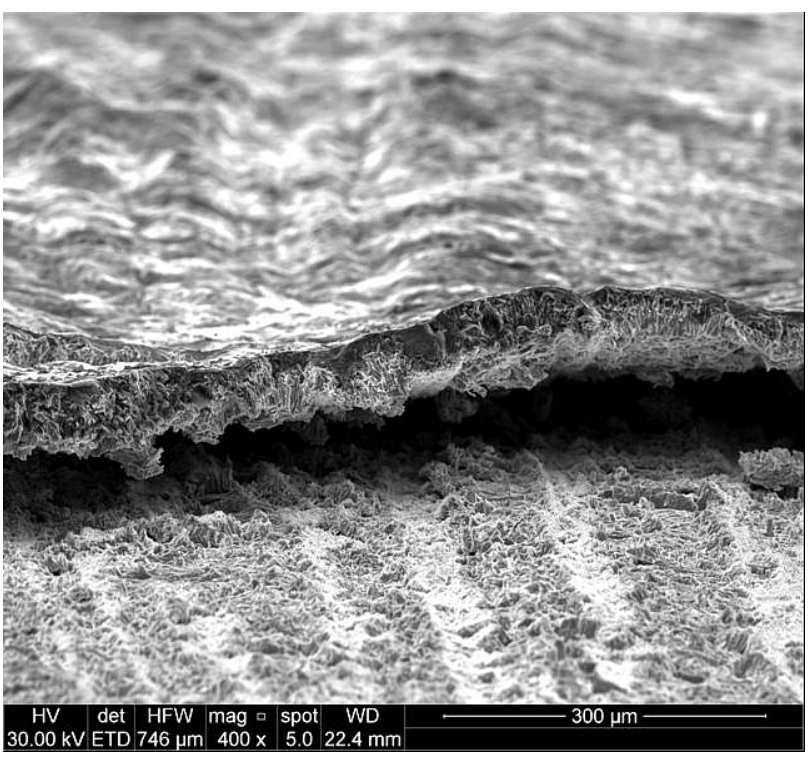

Fig. 4. SEM image of hot-dip galvanized coating on the steel substrate in a specimen after fatigue failure.

2. Results. Figures 5, 6 and 7, 8 display the results from fatigue tests at $R=-1$ and $R=0$ of uncoated and hot-dip galvanized specimens, respectively. The stress range is plotted as a function of the cycles to failure in a double logarithmic scale. The obtained results were statistically elaborated by using a log-normal distribution. The run-out samples, over two million cycles, were not included in the statistical analysis and are marked with an arrow. In addition to the mean curve relative to a survival probability of $P S=50 \%$, Figs. 3-6 show the scatter band defined by lines with 10 and $90 \%$ of survival probability (Haibach's scatter band). For uncoated specimens due to failures occurred between $10^{6}$ and $2 \cdot 10^{6}$ cycles the scatter band is defined between $10^{4}$ and $2 \cdot 10^{6}$ cycles while for hot dip galvanized specimens the scatter band is defined between $10^{4}$ and $10^{6}$ cycles.

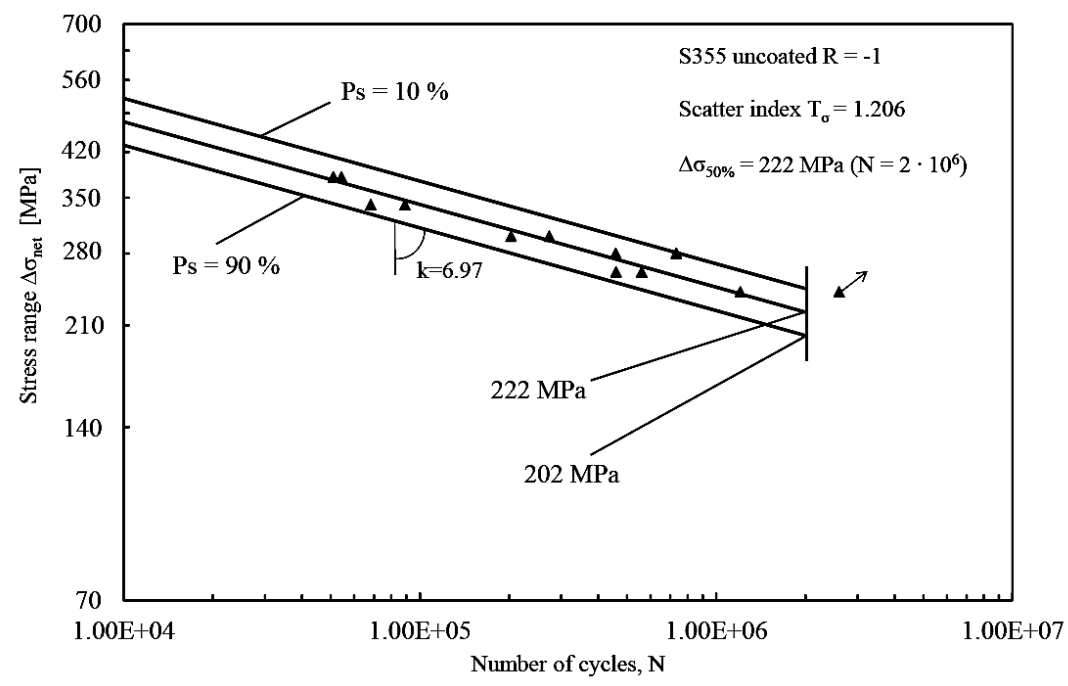

Fig. 5. Fatigue behavior of bare steel at $R=-1$. 


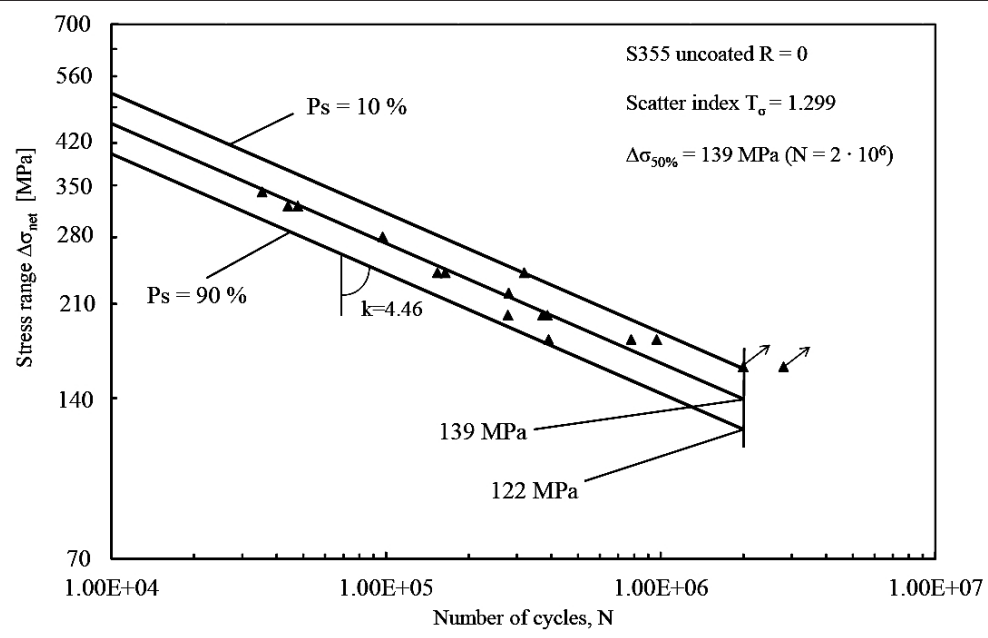

Fig. 6. Fatigue behavior of bare steel at $R=0$.

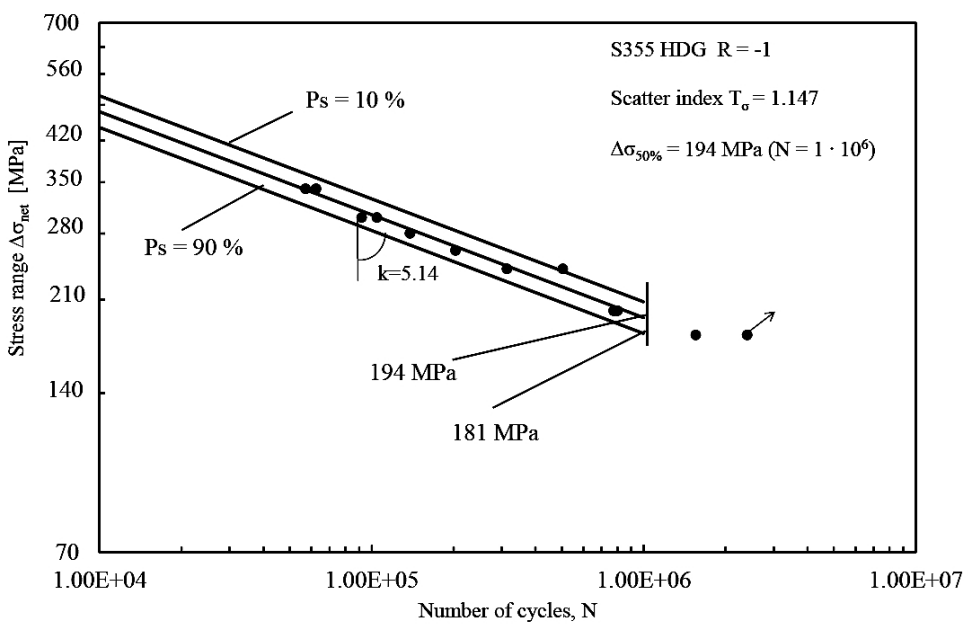

Fig. 7. Fatigue behavior of hot dip galvanized steel at $R=-1$.

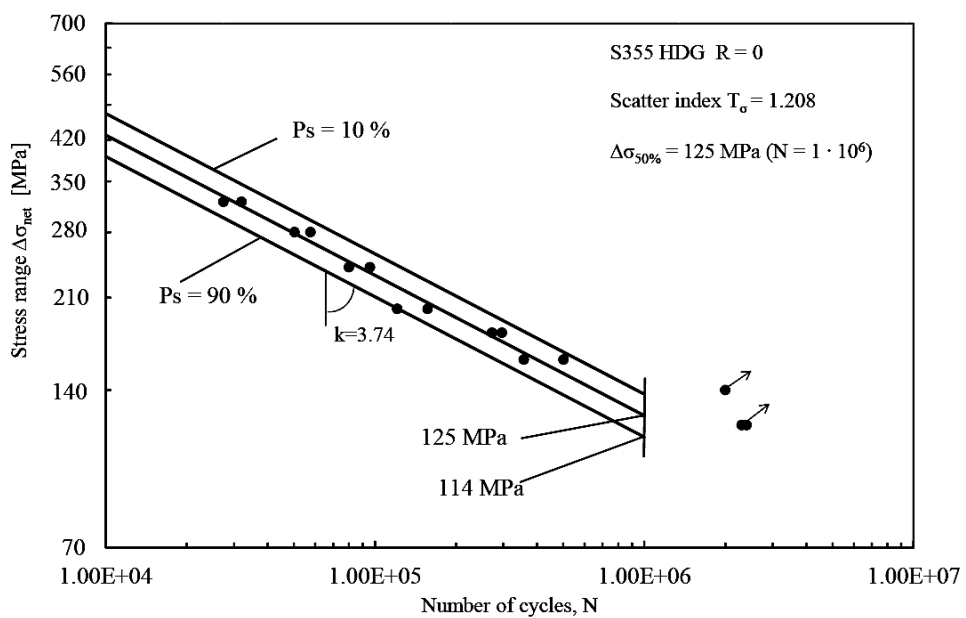

Fig. 8. Fatigue behavior of hot dip galvanized steel at $R=0$. 
The mean stress amplitude values corresponding to two million cycles, the inverse slope $k$ value of the Wöhler curve ( $S-N$ curve) and the scatter index $T$ (the ratio between the stress amplitudes corresponding to 10 and $90 \%$ of survival probability) are also shown. The details of the data for uncoated samples are reported in Table 1 while for hot-dip galvanized specimens a summary is reported in Table 2. The results from statistical re-analyses are summarized in Tables 3-6 for each series.

$\mathrm{T}$ a b 1 e 1

Fatigue Test Results for Uncoated Specimens

\begin{tabular}{|c|c|c|c|}
\hline$\Delta \sigma_{n e t}, \mathrm{MPa}$ & $R$ & $f, \mathrm{~Hz}$ & $\begin{array}{c}\text { Number of cycles } \\
\text { to failure }\end{array}$ \\
\hline 340 & -1 & 10 & 88,992 \\
\hline 240 & & & 2600,151 (run out) \\
\hline 300 & & & 203,261 \\
\hline 280 & & & 457,790 \\
\hline 380 & & & 54,326 \\
\hline 380 & & & 51,028 \\
\hline 280 & & & 733,087 \\
\hline 300 & & & 273,416 \\
\hline 260 & & & 459,547 \\
\hline 260 & & & 561,000 \\
\hline 240 & & & 1206,041 \\
\hline 340 & & & 68,311 \\
\hline 160 & 0 & 10 & 2000,000 (run out) \\
\hline 240 & & & 164,435 \\
\hline 200 & & & 371,772 \\
\hline 320 & & & 44,053 \\
\hline 160 & & & 2800,500 (run out) \\
\hline 240 & & & 318,524 \\
\hline 200 & & & 278,246 \\
\hline 220 & & & 279,556 \\
\hline 200 & & & 387,287 \\
\hline 240 & & & 153,910 \\
\hline 280 & & & 97,416 \\
\hline 180 & & & 780,039 \\
\hline 340 & & & 35,420 \\
\hline 180 & & & 967,055 \\
\hline 320 & & & 47,741 \\
\hline 180 & & & 391,000 \\
\hline
\end{tabular}

$\mathrm{T}$ a b 1 e 2

Fatigue Test Results for Hot Dip Galvanized Specimens

\begin{tabular}{|c|c|c|c|}
\hline$\Delta \sigma_{\text {net }}, \mathrm{MPa}$ & $R$ & $f, \mathrm{~Hz}$ & $\begin{array}{c}\text { Number of cycles } \\
\text { to failure }\end{array}$ \\
\hline 1 & 2 & 3 & 4 \\
\hline 300 & -1 & 10 & 91,942 \\
240 & & & 504,622 \\
\hline
\end{tabular}


Continued Table 2

\begin{tabular}{|c|c|c|c|}
\hline 1 & 2 & 3 & 4 \\
\hline 300 & -1 & 10 & 104,500 \\
\hline 180 & & & 1554,379 \\
\hline 340 & & & 62,500 \\
\hline 240 & & & 314,623 \\
\hline 340 & & & 57,208 \\
\hline 200 & & & 775,999 \\
\hline 200 & & & 776,511 \\
\hline 280 & & & 138,444 \\
\hline 260 & & & 203,443 \\
\hline 180 & & & 2400,000 (run out) \\
\hline 160 & 0 & 10 & 501,500 \\
\hline 240 & & & 95,849 \\
\hline 160 & & & 357,000 \\
\hline 320 & & & 27,400 \\
\hline 320 & & & 32,000 \\
\hline 120 & & & 2300,000 (run out) \\
\hline 120 & & & 2400,000 (run out) \\
\hline 240 & & & 80,070 \\
\hline 140 & & & 2000,000 (run out) \\
\hline 200 & & & 157,000 \\
\hline 180 & & & 272,000 \\
\hline 200 & & & 121,000 \\
\hline 180 & & & 296,154 \\
\hline 280 & & & 57,639 \\
\hline 280 & & & 50,330 \\
\hline
\end{tabular}

$\mathrm{T}$ a b 1 e 3

Statistical Re-Analysis of Data on Hot Dip Galvanized Specimens at $R=0$

\begin{tabular}{|c|c|c|}
\hline$k$ & \multicolumn{2}{|c|}{3.74} \\
\hline$T_{\sigma}(10-90 \%)$ & \multicolumn{2}{|c|}{1.208} \\
\hline$P S, \%$ & $N$, cycles & $\Delta \sigma_{n e t}, \mathrm{MPa}$ \\
\hline 10 & \multirow[t]{3}{*}{$10^{4}$} & 472 \\
\hline 50 & & 429 \\
\hline 90 & & 391 \\
\hline 10 & \multirow[t]{3}{*}{$10^{6}$} & 138 \\
\hline 50 & & 125 \\
\hline 90 & & 114 \\
\hline
\end{tabular}

A direct comparison between uncoated and hot dip galvanized specimens at $R=-1$ and 0 is shown in Figs. 9 and 10, respectively. The solid lines reported in the figures correspond to a probability of survival of $50 \%$. 
$\mathrm{T}$ a b 1 e 4

Statistical Re-Analysis of Data on Hot Dip Galvanized Specimens at $R=-1$

\begin{tabular}{|c|c|c|}
\hline$k$ & \multicolumn{2}{|c|}{5.14} \\
\hline$T_{\sigma}(10-90 \%)$ & \multicolumn{2}{|c|}{1.147} \\
\hline$P S, \%$ & $N$, cycles & $\Delta \sigma_{n e t}, \mathrm{MPa}$ \\
\hline 10 & \multirow[t]{3}{*}{$10^{4}$} & 509 \\
\hline 50 & & 476 \\
\hline 90 & & 444 \\
\hline 10 & \multirow[t]{3}{*}{$10^{6}$} & 208 \\
\hline 50 & & 194 \\
\hline 90 & & 181 \\
\hline
\end{tabular}

$\mathrm{T}$ a b 1 e 5

Statistical Re-Analysis of Data on Uncoated Specimens at $R=0$

\begin{tabular}{|c|c|c|}
\hline$k$ & \multicolumn{2}{|c|}{4.46} \\
\hline$T_{\sigma}(10-90 \%)$ & \multicolumn{2}{|c|}{1.299} \\
\hline$P_{S}, \%$ & $N$, cycles & $\Delta \sigma_{n e t}, \mathrm{MPa}$ \\
\hline 10 & \multirow[t]{3}{*}{$10^{4}$} & 521 \\
\hline 50 & & 457 \\
\hline 90 & & 401 \\
\hline 10 & \multirow[t]{3}{*}{$2 \cdot 10^{6}$} & 159 \\
\hline 50 & & 139 \\
\hline 90 & & 122 \\
\hline
\end{tabular}

$\mathrm{T}$ a b 1 e 6

Statistical Re-Analysis of Data on Uncoated Specimens at $R=-1$

\begin{tabular}{|c|c|c|}
\hline$k$ & \multicolumn{2}{|c|}{6.97} \\
\hline$T_{\sigma}(10-90 \%)$ & \multicolumn{2}{|c|}{1.206} \\
\hline$P S, \%$ & $N$, cycles & $\Delta \sigma_{n e t}, \mathrm{MPa}$ \\
\hline 10 & \multirow[t]{3}{*}{$10^{4}$} & 521 \\
\hline 50 & & 474 \\
\hline 90 & & 431 \\
\hline 10 & \multirow[t]{3}{*}{$2 \cdot 10^{6}$} & 243 \\
\hline 50 & & 222 \\
\hline 90 & & 202 \\
\hline
\end{tabular}




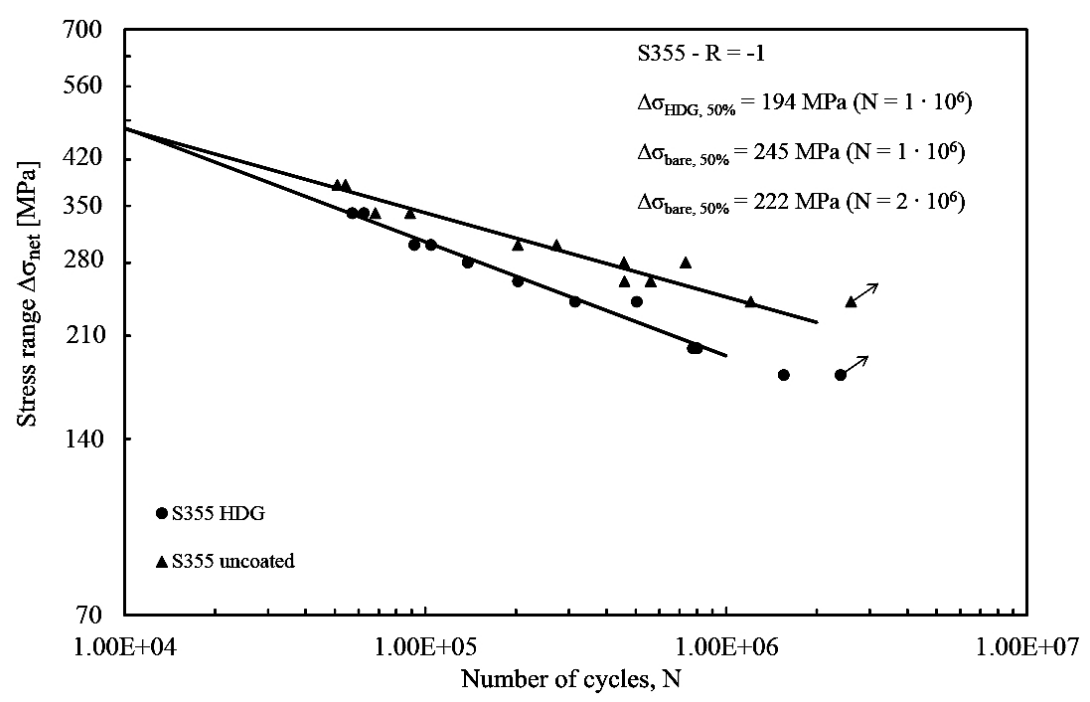

Fig. 9. Comparison of fatigue behavior of uncoated and hot dip galvanized steel at $R=-1$.

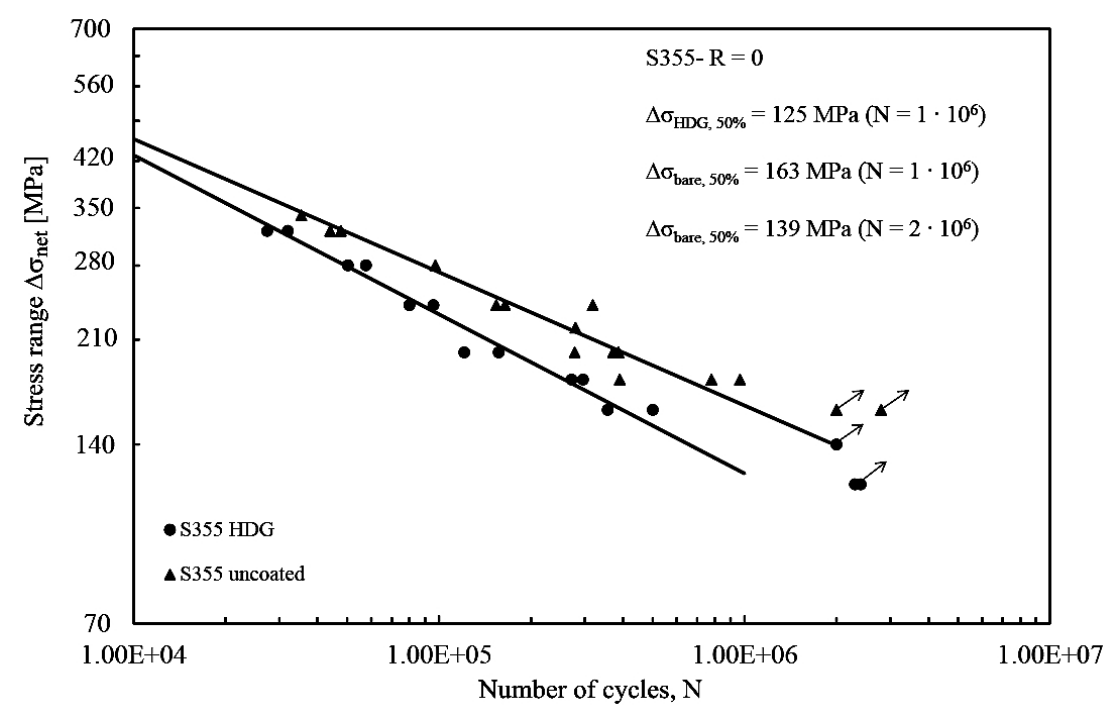

Fig. 10. Comparison of fatigue behavior of uncoated and hot dip galvanized steel at $R=0$.

Table 7 lists the value referred to a probability of survival of $90 \%$ at $10^{6}$ and $2 \cdot 10^{6}$ cycles, respectively, allowing a direct quantification of the fatigue strength reduction factor due to the galvanizing process. From the comparison it can be noted that the stress range at $2 \cdot 10^{6}$ cycles decreases, passing from uncoated to HDG specimens, as expected, with a ratio variable between 1.23 and 1.28 , for $R=-1$, and between 1.25 and 1.28 for $R=0$. A slight decrement of the inverse slope $k$ from bare to galvanized specimens for both load ratios can be also observed. It is worth noting that the stress range results are comparable and higher than the values taken from Eurocode 3 for the detail category 'structural element with holes subject to bending and axial forces' which belongs to the class $\Delta \sigma=90 \mathrm{MPa}$ and is referred to uncoated material. This value is comparable with the stress range $\Delta \sigma=95 / 1.1=86.6 \mathrm{MPa}(P s=97.7 \%)$ found here dealing with hot-dip galvanized specimens weakened by a hole and tested at $R=0$, see Table 7 . The employed coefficient 1.1 allows 
T a b 1 e 7

Comparison of Uncoated Non-Galvanized and Galvanized Specimens $(P s=50 \%)$

\begin{tabular}{|c|c|c|c|c|c|c||}
\hline \multirow{2}{*}{ Characteristic } & \multicolumn{3}{|c|}{$R=0$} & \multicolumn{3}{c||}{$R=-1$} \\
\cline { 2 - 7 } & $\begin{array}{c}N=2 \cdot 10^{6}, \\
\text { cycles }\end{array}$ & $\begin{array}{c}N=10^{6}, \\
\text { cycles }\end{array}$ & $k$ & $N=2 \cdot 10^{6}$, & $\begin{array}{c}N=10^{6}, \\
\text { cycles } \\
\text { cycles }\end{array}$ & $k$ \\
\hline Uncoated $\Delta \sigma, \mathrm{MPa}$ & 122 & 143 & 4.46 & 202 & 223 & 6.97 \\
\hline HDG $\Delta \sigma, \mathrm{MPa}$ & 95 & 114 & 3.74 & 158 & 181 & 5.14 \\
\hline $\begin{array}{c}\text { Reduction ratio } \\
\text { due to galvanizing }\end{array}$ & 1.28 & 1.25 & & 1.28 & 1.23 & \\
\hline \hline
\end{tabular}

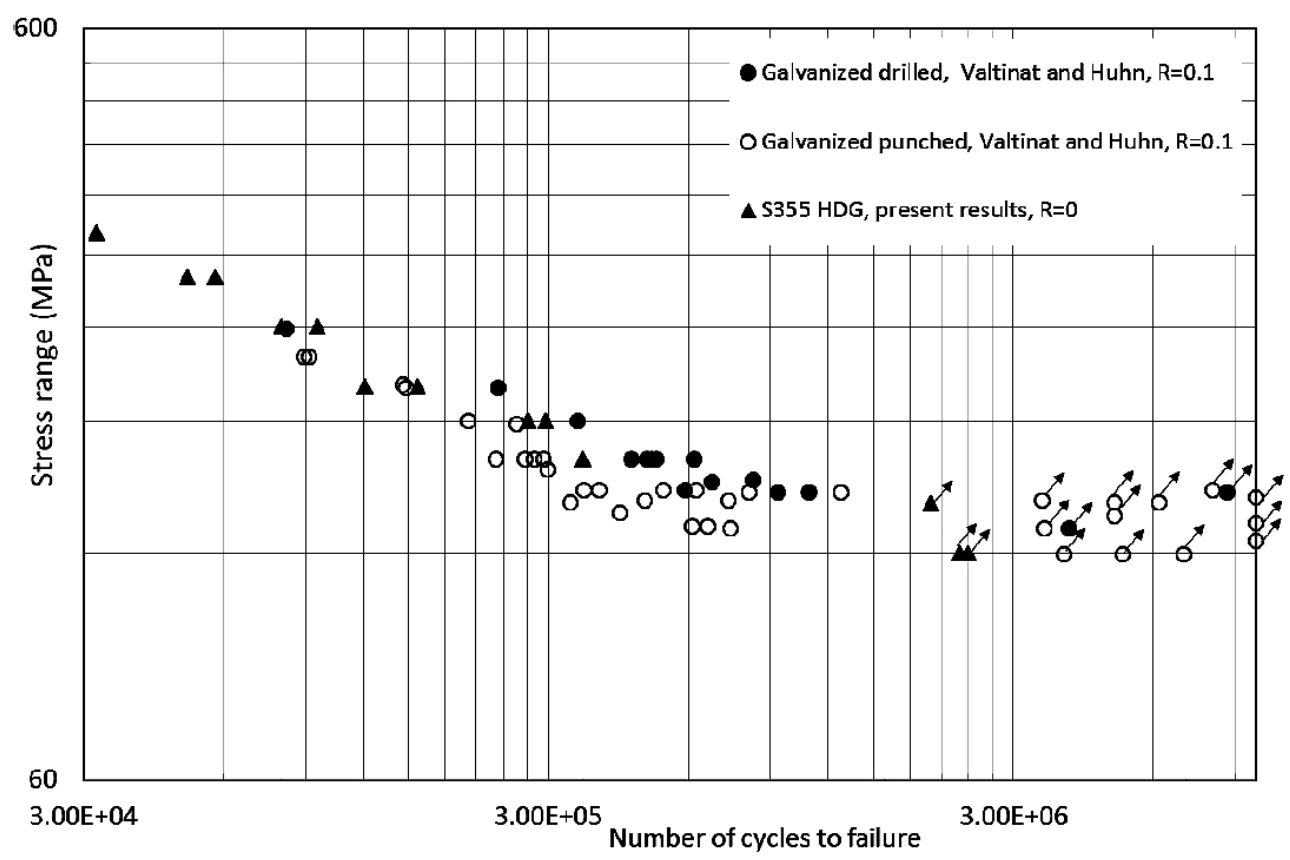

Fig. 11. Direct comparison between the present results at $R=0$ and the fatigue data by [17] for $R=0.1$.

one to convert the probability of survival of $90 \%$ to a probability of survival equal to $97.7 \%$.

The results reported in the present paper are then very promising for possible applications to bolted and welded connections which will be the topic of future contributions.

Finally, a direct comparison has been carried out between the present results obtained at $R=0$ and those by Huhn and Valtinat [17] referred to a nominal load ratio $R=0.1$. As seen from Fig. 11, there is a very good correspondence between the present results and those previously obtained in [17] and, in particular, with those obtained from specimens with drilled holes.

Conclusions. The effect of a galvanizing coating on the fatigue strength of S355 structural steel has been investigated. A direct comparison is carried out between hot dip galvanized specimens weakened by a central hole and untreated specimens characterized by the same geometry. Two different values of the nominal load ratio are considered with 
$R=0$ and -1 , respectively. Almost 60 new experimental data are summarized in the present contribution. The degree of penalization due to hot dip galvanization process is about $25 \%$ in terms of fatigue strength for the specimens considered in the present investigation and it is almost independent on the load ratio $R$. Even if this penalization is not negligible, the fatigue strength of the hot dip galvanized specimens is comparable and also higher than the reference value reported in Eurocode 3 for structural elements with holes subject to bending and axial forces. The present results are also in very good agreement with a previous study by Huhn and Valtinat [17], which refer both to drilled and punched holes in hot dip galvanized specimens.

\section{Резюме}

Досліджено вплив гальванічного покриття на втомну міцність конструкційної сталі $\mathrm{S} 355$. Незважаючи на те, що в літературних джерелах є експериментальні дані щодо гладких зразків із цього матеріалу з покриттям, майже відсуті дані щодо зразків із концентратором напружень. Виконано порівняльний аналіз зразків із центральним отвором, ще зазнали гальванізації методом гарячого занурення, і вихідних зразків такої ж геометрії. Випробування на втому проводились при двох постійних значеннях асиметрії циклу навантаження. Отримано і проаналізовано 60 нових експериментальних даних.

1. Y. Bergengren and A. Melander, "An experimental and theoretical study of the fatigue properties of hot dip-galvanized high strength sheet steel," Int. J. Fatigue, 14, 154-162 (1992).

2. T. Nilsson, G. Engberg, and H. Trogen, "Fatigue properties of hot-dip galvanized steels," Scand. J. Metallurgy, 18, 166-175 (1989).

3. R. S. Browne, E. N. Gregory, and S. Harper, "The effects of galvanizing on the fatigue strengths of steels and welded joints," in: Proc. of Seminar on Galvanizing of Silicon Containing Steels, ILZRO Publishers, Liege (1975), pp. 246-264.

4. J. B. Vogt, O. Boussac, and J. Foct, "Prediction of fatigue resistance of a hot-dip galvanized steel," Fatigue Fract. Eng. Mater. Struct., 23, 33-39 (2000).

5. J. H. Jiang, A. B. Ma, W. F. Weng, et al., "Corrosion fatigue performance of pre-split steel wires for high strength bridge cables," Fatigue Fract. Eng. Mater. Struct., 32, 769-779 (2009).

6. W. J. Yang, P. Yang, X. M. Li, and W. L. Feng, "Influence of tensile stress on corrosion behaviour of high-strength galvanized steel bridge wires in simulated acid rain," Mater. Corros., 63, 401-407 (2012).

7. K. Berchem and M. G. Hocking, "The influence of pre-straining on the corrosion fatigue performance of two hot-dip galvanised steels," Corros. Sci., 48, 4094-4112 (2006).

8. K. Berchem and M. G. Hocking, "The influence of pre-straining on the high-cycle fatigue performance of two hot-dip galvanised car body steels," Mater. Character., 58, 593-602 (2006).

9. A. Dimatteo, G. Lovicu, M. DeSanctis, et al., "Influence of galvanizing process on fatigue resistance of microalloyed steels," in: Convegno Nazionale IGF XXI, Cassino, Italy (2011), pp. 283-291.

10. P. De la Cruz and T. Ericsson, "Influence of hot dip galvanizing on fatigue and corrosion fatigue resistance of a B-Mn steel," Scand. J. Metallurgy, 26, 145-152 (1997). 
11. B. Mintz, "Hot dip galvanising of transformation induced plasticity and other intercritically annealed steels," Int. Mater. Rev., 46, 169-197 (2001).

12. G. Reumont, J. B. Vogt, A. Iost, and J. Foct, "The effects of an Fe-Zn intermetalliccontaining coating on the stress corrosion cracking behavior of a hot-dip galvanized steel," Surf. Coat. Technol., 139, 265-271 (2001).

13. C. Ma, D. L. Chen, S. D. Bhole, et al., "Microstructure and fracture characteristics of spot-welded DP600 steel," Mater. Sci. Eng. A, 485, 334-346, (2008).

14. M. N. James, "Designing against LMAC in galvanised steel structures," Eng. Fail. Anal., 16, 1051-1061 (2009).

15. S. Aden-Ali, A. Chamat, J. Gilgert, et al., "On the degradation the endurance of silicon-rich TRIP800 steel after hot-dip galvanization," Eng. Fail. Anal., 16, 20092019 (2009).

16. P. Maass and P. Peissker, Handbook of Hot-Dip Galvanization, Wiley-VCH, Weinheim (2011).

17. H. Huhn and G. Valtinat, "Bolted connections with hot dip galvanized steel members with punched holes," in: Connections in Steel Structures, Vol. 5, Amsterdam (2004), pp. 304-308. 